\title{
CD36 Peptides That Block Cytoadherence Define the CD36 Binding Region for Plasmodium falciparum-Infected Erythrocytes
}

\author{
By Dror I. Baruch, Xin C. Ma, Brittan Pasloske, Russell J . Howard, and Louis H. Miller
}

\begin{abstract}
Mature Plasmodium falciparum parasitized erythrocytes (PE) sequester from the circulation by adhering to microvascular endothelial cells. PE sequestration contributes directly to the virulence and severe pathology of falciparum malaria. The scavenger receptor, CD36, is a major host receptor for PE adherence. PE adhesion to CD36 is mediated by the malarial variant antigen, $\boldsymbol{P}$. falciparum erythrocyte membrane protein 1 (PFEMP1), and particularly by its cysteine-rich interdomain region 1 (CIDR-1). Several peptides from the extended immunodominant domain of CD36 (residues 139-184), including CD36 139-155, CD36 145-171, CD36 146-164, and CD36 156184 interfered with the CD36-PFEMP1 interaction. Each of these peptides affected binding at the low micromolar range in 2 independent assays. Two peptides, CD36 145-171 and
\end{abstract}

QEQUESTRATION OF MATURE stage parasitized erythrocytes (PE) is central for the survival and the pathology of P. falciparum parasites. ${ }^{1-4}$ Adherence of P. falciparum PE to endothelial cells in various blood vessels can result in local microvascular occlusion contributing directly to the pathology of $P$. falciparum malaria. ${ }^{1,5,6}$

Adherence of PE to endothelial cells is mediated by the binding of the infected erythrocyte to host receptors expressed on endothelial cells including CD36, thrombospondin (TSP), intercellular adhesion molecule-1 (ICAM-1), and chondroitin sulfate A. ${ }^{2,7-10}$ Other molecules such as vascular cell adhesion molecule-1 (VCAM-1), E-selectin, and CD31 mediate adherence of a minority of $P$. falciparum parasites. ${ }^{11-13}$ CD36 may play a predominant role in $\mathrm{PE}$ adherence, as almost all adherence positive $P$. falciparum strains and isolates bind to CD36. ${ }^{13}$ There is a significant correlation between PE sequestration and expression of CD36 (and ICAM-1) in various organs and vascular endothelium. ${ }^{5,14}$ Under flow conditions, which mimic in vivo blood flow, CD36 supports stable stationary adherence of PE, while ICAM-1 mediates PE rolling and adherence to TSP appears to be unstable. ${ }^{15}$ Recently, a recombinant protein from $P$. falciparum erythrocyte membrane protein 1 (PfEMP1), named $\mathrm{rC1}-2$, located in the first cysteine-rich interdomain region (CIDR-1) immediately after the first Duffy binding-like (DBL) domain was shown to mediate PE adherence to CD36. ${ }^{16,17}$

CD36 is an $88-\mathrm{kD}$ glycoprotein scavenger receptor expressed on the surface of various cells including platelets, adipocytes, monocytes, macrophages, leukocytes, megakaryocytes, erythroblasts, melanoma cells, and endothelial cells.5,18,19 Several CD36 genes cloned from different organisms display high sequence conservation. ${ }^{20}$ In the last years, several other proteins were found to have sequence and structural homology with CD36. This includes the type B scavenger receptor SR-BI/ CLA-1, the lysosomal protein LIMP II, 2 Drosophila proteins, and a Caenorhabditis elegans protein, all members of the CD36 gene family. ${ }^{20-22} \mathrm{CD} 36$ is implicated in uptake of oxidized low-density lipoproteins (ox-LDL), long chain fatty acids, anionic phospholipids, phagocytosis of apoptotic neutrophils, and in signal transduction. ${ }^{23-30}$ CD36 can interact with a wide
CD36 156-184, specifically blocked PE adhesion to CD36 without affecting binding to the host receptor intercellular adhesion molecule-1 (ICAM-1). Moreover, an adhesion blocking peptide from the ICAM-1 sequence inhibits the PFEMP1ICAM-1 interaction without affecting adhesion to CD36. These results confirm earlier obsenvations that PFEMP1 is also a receptor for ICAM-1. Thus, the region 139-184 and particularly the 146-164 or the 145-171 regions of CD36 form the adhesion region for $P$. falciparum $P$. Adherence blocking peptides from this region may be useful for modeling the PE/PFEMP1 interaction with CD36 and for development of potential anti-adhesion therapeutics.

(c) 1999 by The American Society of Hematology.

range of different molecules including ox-LDL, the extracellular matrix proteins collagen and TSP, and the malarial protein PfEMP1. 17,20,27,29,31-35

Several anti-CD36 monoclonal antibodies (MoAbs) (8A6, OKM5, FA6-152, and 10/5) that block binding of ox-LDL and recognition of apoptotic neutrophils react with the CD36 immunodominant domain, defined by residues $155-183.33,34,36$ These MoAbs also efficiently block adhesion of PE to human CD $36 .{ }^{8}$ However, it was recently shown ${ }^{37}$ that the binding domain for ox-LDL resides elsewhere (residues 28-93) on CD36. Thus, these MoAbs block a function that resides outside the immunodominant region (155-183) of CD36, either by steric hindrance or by changing the conformation of CD36 required for binding. The binding domains for collagen and TSP were ascribed to the 415-427 and the 93-120 regions, respectively. ${ }^{31,32}$ Residues $139-155$, located just before the immunodominant domain, were shown to induce a conformational change in TSP, which leads to higher affinity interaction between TSP and the 93-110 region of CD36. ${ }^{27,38}$

The inhibitory effect of MoAbs specific for the 155-184 region suggests that the binding domains for the inhibitory MoAbs and for PE overlap. However, PE bind to both human and mouse CD36, although only the human CD36 is recognized by the inhibitory MoAbs. ${ }^{39,40}$ This significant difference indi-

From the Laboratory of Parasitic Diseases, National Institute of Allergy and Infectious Diseases, National Institutes of Health, Bethesda, MD; and Affymax Research Institute, Santa Clara, CA.

Submitted November 3, 1998; accepted May 12, 1999.

Supported by Affymax Research Institute and Grant No. (HRN-6001A-00-2043-00) to R.J.H from the United States Agency for International Development Malaria Vaccine Development Program.

Address reprint requests to Dror I. Baruch, MD, Laboratory of Parasitic Diseases, NIAID, NIH Bldg 4, Room B1-37, 4 Center Dr, MSC 0425, Bethesda, MD 20892; e-mail: dbaruch@ niaid.nih.gov.

The publication costs of this article were defrayed in part by page charge payment. This article must therefore be hereby marked "advertisement" in accordance with 18 U.S.C. section 1734 solely to indicate this fact.

(C) 1999 by The American Society of Hematology.

0006-4971/99/9406-0009\$3.00/0 
cates that inhibitory MoAbs and infected erythrocytes recognize different residues of the CD36 multifunctional domain or that residues outside this region contribute significantly to the PE-CD36 interaction.

To study the region(s) of CD36 involved in binding of PfEMP1 and PE adhesion, we made a set of peptides from different regions of CD36 and tested their ability to inhibit the PfEMP1-CD36 interaction and to block PE adhesion.

\section{MATERIALS AND METHODS}

Parasites. Malayan Camp (MC $\left.\mathrm{R}^{+}\right)$and the FCR3-C5 P. falciparum strains adhere to the host receptors CD36 and TSP, but not ICAM-1. The ItG2-ICAM strain and clone A4ultra adhered to all 3 host receptors. ${ }^{16,35}$

Peptides. CD36-derived peptides CD36 62-75 (residues 62-75), CD36 233-250 (residue 238 (Lys) was replaced by a Tyr residue), CD36 358-370, CD36 397-409, and CD36 413-426 (with an additional Tyr residue) were custom synthesized by Bio-Synthesis Inc, (Lewisville, TX). Peptides CD36 139-155 and CD36 93-110 were synthesized both by Neuros Corp (San Jose, CA) and by Affymax Research Institute (Santa Clara, CA). Peptides CD36 93-110C and CD36 C139-155 with additional terminal cysteines at the carboxyl- or amino-terminus, respectively, were purchased from Bachem California (Torrance, CA) and also synthesized at Affymax Research Institute. Peptides CD36 139-149, CD36 142-152, and CD36 146-155 were synthesized by SynPeP Corporation (Dublin, CA). A scrambled version of the CD36 139-155 was also synthesized, but was largely insoluble even at $100 \%$ dimethyl sulfoxide (DMSO). Peptides CD36 145-171, CD36 146-164, and CD36 156-184 were synthesized by the support facility, NIAID, NIH. The ICAM 15-20 was synthesized at Affymax Research Institute. The amino acid sequences of the peptides are described in Table 1. All peptides were synthesized by the Fmoc method, purified to homogeneity by high-performance liquid chromatography (HPLC) and confirmed structurally by mass spectrometry. Peptide concentration was determined by BCA protein assay (Pierce, Rockford, IL).

Soluble receptors. Soluble CD36 extracellular domain was obtained in the form of harvest supernatant (approximately 1 to $5 \mu \mathrm{g} / \mathrm{mL}$ ) after phospholipase $\mathrm{C}$ treatment of cultured cells as described before ${ }^{35}$ Soluble ICAM-1 extracellular domain carrying the Protein A Ig binding domain (ZZ-ICAM) was a gift from Dr Andrew Hutchinson (GlaxoWellcome, Stevange, UK).

Antibodies. Mouse MoAb 179 (Affymax Research Institute) recognizes an epitope sequence incorporated into the carboxy terminus of CD36. Mouse MoAb 141 (Affymax Research Institute) recognizes GST. ${ }^{17,35}$ Rabbit IgG was purchased from Jackson Immunoresearch Labs (West Grove, PA).

Affinity purification of surface radiolabeled PfEMP1. PE were surface radioiodinated and sequentially extracted with triton X-100 (TX100) and sodium dodecyl sulfate (SDS) as described. ${ }^{35}$ Inhibition of binding of PfEMP1 to sCD36 or ICAM-1 was as described. ${ }^{35}$ Briefly, 5 to $10 \mu \mathrm{L}$ of PE SDS extracts were reconstituted in $1 \mathrm{~mL}$ of $25 \mathrm{mmol} / \mathrm{L}$ HEPES, $1 \%$ bovine serum albumin (BSA) $0.5 \%$ TX100 in RPMI- 1640 (BM-T, binding medium containing TX100) at $\mathrm{pH} 6.7$ for $\mathrm{CD} 36$ and $\mathrm{pH}$ 7.3 for ICAM-1. Peptides dissolved in DMSO were added to the appropriate concentration. DMSO was added to give a final concentration of 5\% DMSO. The reconstituted SDS extracts were incubated, 16 hours at $4^{\circ} \mathrm{C}$, with CD36-derived peptides or, 1 hour at $21^{\circ} \mathrm{C}$, with peptide ICAM-1 $15-20$ followed by incubation, 3 hours at $21^{\circ} \mathrm{C}$, with immobilized receptor, and processed as described. ${ }^{35}$

Affinity-purification of CD36 with immobilized recombinant fragments of PfEMP1. Affinity-purification of CD36 with immobilized rC1-2 [1-179] (GST-fusion) was described earlier. ${ }^{17}$ Briefly, $25 \mu \mathrm{L}$ of GammaBind Plus Sepharose beads (Pharmacia Biotech Inc, Piscataway, $\mathrm{NJ}$ ) were precoated, 90 minutes $21^{\circ} \mathrm{C}$, with $10 \mu \mathrm{g}$ of MoAb 141
(anti-GST), then incubated with $2.5 \mu \mathrm{g}$ of rC1-2 [1-179]. The coated beads were incubated 60 minutes at $21^{\circ} \mathrm{C}$, with $450 \mu \mathrm{L}$ of $\mathrm{BM}$ containing peptides and 5\% DMSO final concentration. A total of $50 \mu \mathrm{Ll}$ of soluble CD36 (0.5 to $1 \mu \mathrm{g} / \mathrm{mL}$ ) was added and incubated 2 hours at $21^{\circ} \mathrm{C}$. The beads were washed twice with $\mathrm{BM}$, once with $\mathrm{BM}$ without BSA, and solubilized in $40 \mu \mathrm{L}$ of SDS sample buffer. One to $2.5-\mu \mathrm{L}$ samples were fractionated by SDS-polyacrylamide gel electrophoresis (SDS-PAGE), immunoblotted, and probed with a 1:10,000 dilution of biotinylated MoAb 179 as primary antibody followed with horseradish peroxidase (HRP)-conjugated streptavidin (Jackson Immunoresearch Inc) at 1:5,000 dilution.

Densitometry. Autoradiographs were scanned and individual bands were quantified after background subtraction using the NIH Image 1.61 standard program.

Cytoadherence microassay. Adherence of PE to immobilized proteins was performed by standard methods. ${ }^{17,41,42}$ For ICAM-1 binding, plates were spotted with $50 \mu \mathrm{g} / \mathrm{mL}$ of rabbit IgG and incubated with 25 $\mu \mathrm{g} / \mathrm{mL}$ of ZZ-ICAM. Blockade of PE adherence by the different peptides was tested by preincubating, 1 hour at $37^{\circ} \mathrm{C}$, PE in $\mathrm{BM}$ media ( $0.2 \%$ BSA) containing peptides and $1 \%$ DMSO final concentration. PE were added to the spotted receptors, incubated, 1 hour at $37^{\circ} \mathrm{C}$, washed 4 times with BM, fixed, stained, and counted. ${ }^{42}$

\section{RESULTS}

CD36 and ICAM-1-derived peptides inhibit the binding of PfEMP1 to CD36 and ICAM-1, respectively. A panel of CD36 peptides $^{27}$ (Fig 1) were assayed at $500 \mu \mathrm{mol} / \mathrm{L}(300 \mu \mathrm{mol} / \mathrm{L}$ for peptide CD36 233-150) for their effects on the binding of ${ }^{125} \mathrm{I}-\mathrm{PfEMP} 1$ from the Malayan Camp $\left(\mathrm{MC} \mathrm{R}^{+}\right.$) strain (Fig 1A) and clone $\mathrm{FCR}_{3}-\mathrm{C} 5$ (Fig 1B) to CD36. Addition of DMSO (5\%) had very little effect (Fig 1B), but in some of the assays, a 50\% reduction in binding was observed (Fig 1A). Therefore, in each assay, the effect of each peptide was measured and compared with the binding of the DMSO control (100\% binding). Peptides CD36 139-155, CD36 62-75, and CD36 233-250 blocked the CD36-PfEMP1 interaction by more than $50 \%$ for MC and $40 \%$ for $\mathrm{FCR}_{3}$-C5 (Fig 1). Peptide CD36 139-155 was the most active, affecting binding by $70 \%$ to $82 \%$. Other peptides either increased binding or had very limited effect (up to 20\%). The different effects of peptides on specific PfEMP1 bands is attributed to the variant sequence of different PfEMP1 molecules. ${ }^{17,41,43}$ Three partial peptides from the 139-155 region (CD36 139-149, CD36 142-152, and CD36 145-155, Table 1) had no effect on binding (unpublished data).

Dose response assays with the 3 active peptides demonstrated that peptides CD36 62-75 and CD36 233-250 were active only at high concentrations ( 250 to $300 \mu \mathrm{mol} / \mathrm{L}$ ) and actually increased binding at concentrations of $100 \mu \mathrm{mol} / \mathrm{L}$ or lower (Fig $2 \mathrm{~A})$. Thus, the activity of these peptides may not be highly specific for the PfEMP1-CD36 interaction. On the other hand, peptide CD36 139-155 had an apparent 50\% inhibition $\left(\mathrm{IC}_{50}\right)$ of $\approx 5 \mu \mathrm{mol} / \mathrm{L}$ (Fig 2A and Table 2). The peptide had no effect on the binding of ItG-ICAM PfEMP1 to ICAM-1 (not shown), indicating that its blocking activity is specific for the PfEMP1CD36 interaction. To verify these results, 3 preparations of peptide CD36 139-155 derived from independent sources were assayed and found to consistently block binding of PfEMP1 to CD36.

Peptide ICAM-1 15-20 blocks adherence of intact PE (ItG2ICAM strain) to ICAM-1.44 This peptide also blocked the binding of ItG2-ICAM PfEMP1 to ICAM-1 at a concentration of $100 \mu \mathrm{mol} / \mathrm{L}$ or higher with an $\mathrm{IC}_{50}$ of about $200 \mu \mathrm{mol} / \mathrm{L}$ (Fig 2B). 


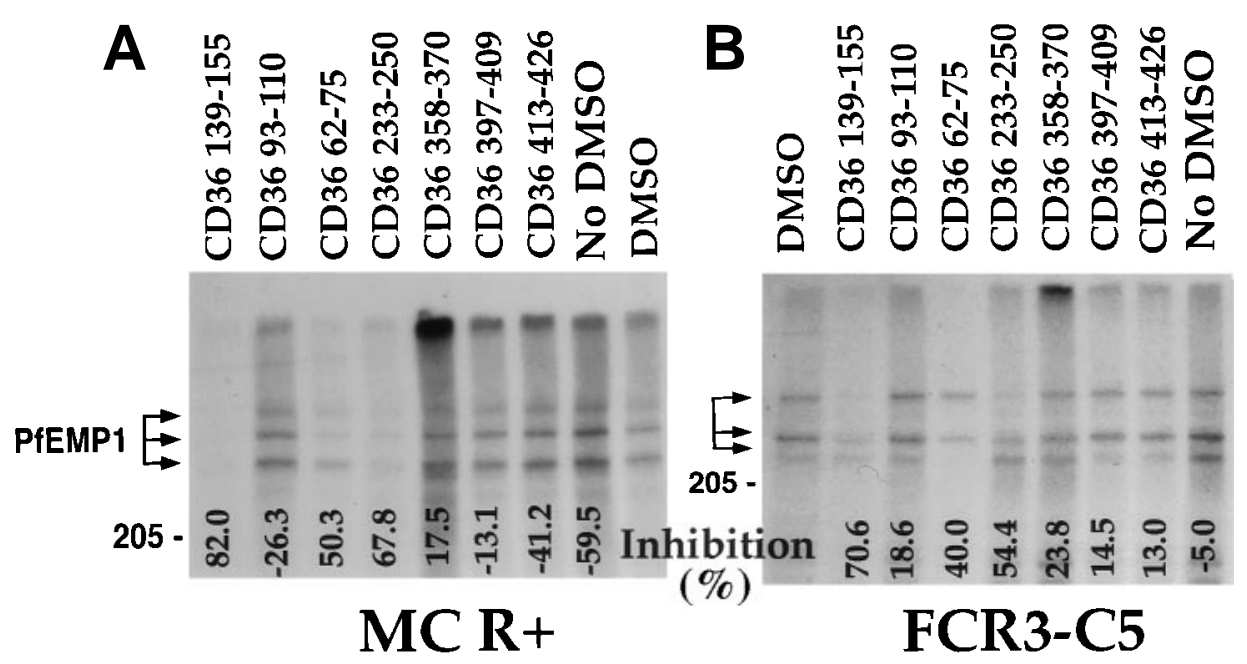

Fig 1. CD36 peptides inhibit the binding of 125I-PFEMP1 to CD36. TX100 insoluble material from surface iodinated PE was extracted with SDS (SDS extract) and reconstituted in RPMI containing 1\% BSA and 0.5\% TX100.35 Peptides dissolved in DMSO were added to the sample, incubated ovemight, and allowed to bind to CD36-coated beads for 3 hours. The beads were washed 3 times and processed for SDS-PAGE as before. 35 Peptides were tested at $500 \mu \mathrm{mol} / \mathrm{L}$, except for peptide CD36 233-255, which was tested at $300 \mu \mathrm{mol} / \mathrm{L}$. All samples except No DMSO, had a 5\% final concentration of DMSO. The percent inhibition of binding from the DMSO control is indicated at the bottom of the figure. Negative numbers means higher binding than the DMSO control. (A) MC R+ SDS extract; (B) FCR - -C5 SDS extract. The percent inhibition of peptide CD36 $358-370$ with FCR3-C5 extract was calculated without the specific background subtraction.

The peptide did not block the interaction of MC PfEMP1 with CD36 (not shown). These results are consistent with independent binding domains for CD36 and ICAM-1 on PfEMP1..$^{35,45}$

CD36-derived peptides block binding of rC1-2 [1-179] to CD36. A region from the CIDR-1 domain of MC-PfEMP1, represented by the recombinant protein $\mathrm{rC1}-2$, was recently demonstrated to bind CD36 and to mediate PE adherence to CD36. ${ }^{17}$ Peptide CD36 139-155 blocked the interaction of CD36 with rC1-2 [1-179] with apparent $\mathrm{IC}_{50}$ of about $2 \mu \mathrm{mol} / \mathrm{L}$ (Fig 3 and Table 2). At $50 \mu \mathrm{mol} / \mathrm{L}$, peptides CD36 62-75 and CD36 233-250, which blocked binding of PfEMP1 to CD36 at high concentrations (Fig 2), had little (23.1\%) to no effect $(6.3 \%)$ on this interaction compared with $78 \%$ to $92 \%$ inhibition

Table 1. Amino Acid Sequence of the Different CD36 and ICAM-1 Peptides

\begin{tabular}{ll}
\hline \multicolumn{1}{c}{ Peptide } & \multicolumn{1}{c}{ Sequence } \\
\hline CD36 62-75 & YRQFWIFDVQNPQE \\
CD36 93-110 & YRVRFLAKENVTQDAEDN \\
CD36 93-110C & YRVRFLAKENVTQDAEDN (C) \\
CD36 139-155 & NLAVAAASHIYQNQFVQ \\
CD36 C139-155 & (C) NLAVAAASH IYQNQFVQ \\
CD36 139-149 & NLAVAAASHIY \\
CD36 142-152 & VAAASHIYQNQ \\
CD36 146-155 & SHIYQNQFVQ \\
CD36 145-171 & ASHIYQNQFVQMILNSLINKSKSSMFQ \\
CD36 146-164 & SHIYQNQFVQMILNSLINK \\
CD36 156-184 & MILNSLINKSKSSMFQVRTLRELLWGYRD \\
CD36 233-250 & KRNLS (Y) *WESHCDMINGTD \\
CD36 358-370 & DGLNPNEEEHRTY \\
CD36 397-409 & EKIQVLKNLKRNY \\
CD36 413-426 & ILWLNETGTIGDEK (Y) \\
ICAM-1 15-20 & GSVLVT \\
\hline
\end{tabular}

Residues added or modified from the original human sequence are marked by parenthesis.

*Residue 238 (Lys) was modified to (Tyr). with peptide CD36 139-155 (Fig 3). Peptides CD36 139-149 and CD36 142-152, but not peptide CD36-145-155, blocked the binding of CD36 to $\mathrm{rC1}-2$ (1-179) (Fig 3A). Some of this activity may be attributed to the highly hydrophobic nature of the first 2 peptides. Also, these assays are not truly quantitative, but demonstrate the range of effective inhibition of binding of each peptide.

Earlier studies suggested that the adherence blocking MoAb OKM5 recognizes the 139-155 region of CD36. ${ }^{27}$ Humanmouse hybrids of CD36 demonstrated that OKM5, 15.2, and other adherence blocking MoAbs actually recognize the adjacent region (155-183) of CD36. ${ }^{39}$ Therefore, additional peptides from the 155-184 and 139-184 regions were synthesized (see Table 1) and measured for their effect on binding of CD36 to the rC1-2 [1-179] GST fusion protein (Fig 3 and Table 2). Peptides CD36 146-164 and CD36 156-184 inhibited the CD36-rC1-2 [1-179] interaction at $50 \mu \mathrm{mol} / \mathrm{L}$ (Fig 3A) and were active even at a concentration of $0.1 \mu \mathrm{mol} / \mathrm{L}$ (Fig 3B). Peptide CD36 156-184 was also active at $0.01 \mu \mathrm{mol} / \mathrm{L}$ (only partial inhibition), while peptide CD36 146-164 appeared to be inactive at this concentration (data not shown). Peptide CD36 145-171 inhibition profile for the $\mathrm{rC} 1-2$ [1-179]-CD36 interaction was similar to that of CD36 146-164 (not shown). Thus, peptides from both regions, CD36 139-155 and CD36 156-184, represent sites of CD36, which interact with the PE receptor, PfEMP1.

The inhibitory effect of different peptides is influenced by their solubility. The relative solubility of the various peptides was determined by the appearance and the size of a precipitate after centrifugation. Although this does not give an accurate measurement of solubility and of the actual concentration of soluble material, it gives a good indication if a peptide is only partially or completely soluble at the conditions of each assay. Peptide CD36 156-184 was soluble even at high concentrations $(>250 \mu \mathrm{mol} / \mathrm{L})$. However, several of the active peptides, mainly CD36 139-155 and CD36 146-164, were not completely soluble 


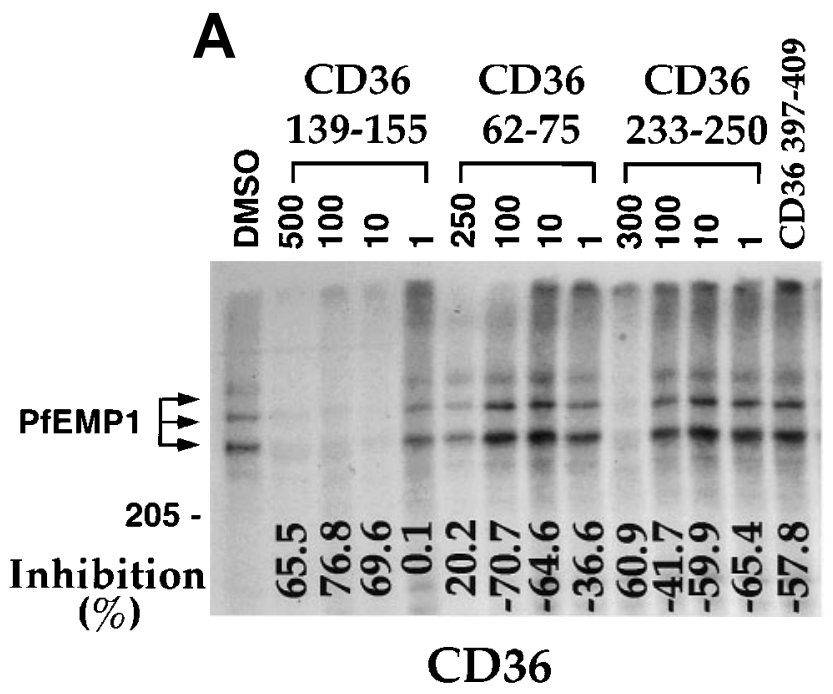

at concentrations higher than 50 to $100 \mu \mathrm{mol} / \mathrm{L}$, as large precipitates were observed and removed by centrifugation. This observation explains the reduction of inhibition associated with high peptide concentrations for some peptides (D. Baruch, unpublished observations). Peptide CD36 145-171 solubility was higher than CD36 146-164, but not as good as CD36 155-184. Thus, at the high $\mu \mathrm{mol} / \mathrm{L}$ range, the actual final concentration of the peptide in the assay solution may be lower, depending on the relative solubility of the peptide in the assay solution. This is particularly important in blockade of adherence assays. In this assay, the amount of DMSO must be restricted to $1 \%$ (final) compared with 5\% DMSO or 5\% DMSO/0.5\% TX100/ $0.1 \%$ SDS used in the affinity purification assays. Moreover, significantly higher peptide concentration is needed to block the interaction of the multivalant PE with CD36. Thus, marginally soluble peptides may not be soluble at the concentration required for blockade of $\mathrm{PE}$ adherence, although they may

Table 2. Approximate IC $\mathrm{C}_{50}$ Values of Peptides Inhibiting the Interaction of PFEMP1 or Infected Erythrocytes With CD36 or ICAM-1

\begin{tabular}{cccc}
\hline & \multicolumn{3}{c}{$\mathrm{IC}_{50}(\mu \mathrm{mol} / \mathrm{L})$} \\
\cline { 2 - 4 } Peptide & $\begin{array}{c}\text { Binding } \\
\text { of PfEMP1 }\end{array}$ & $\begin{array}{c}\text { Binding } \\
\text { of } \mathrm{rCl}-2\end{array}$ & $\begin{array}{c}\mathrm{PE} \\
\text { Adherence }\end{array}$ \\
\hline Binding to CD36 & & & $\mathrm{ND}$ \\
CD36 62-75 & 250 & $\mathrm{ND}$ & $\mathrm{ND}$ \\
CD36 139-155 & 5.9 & 0.6 & $>100^{*}$ \\
CD36 145-171 & $\mathrm{ND}$ & $<0.1$ & 86 \\
CD36 146-164 & $\mathrm{ND}$ & $<0.1$ & $>100^{*}$ \\
CD36 156-184 & $\mathrm{ND}$ & $<0.01$ & 24.5 \\
CD36 233-250 & 205.9 & $\mathrm{ND}$ & $\mathrm{ND}$ \\
Binding to ICAM-1 & & & \\
ICAM-1 15-20 & 208.3 & $\mathrm{ND}$ & 79 \\
\hline
\end{tabular}

Results summarize the approximate $\mathrm{IC}_{50}$ values of peptide inhibition on the binding of soluble 125I-PfEMP1 to immobilized CD36, binding of CD36 to immobilized rC1-2 [1-179] and inhibition of PE adhesion. Binding of 125I-PfEMP1 to CD36 was measured with SDS extract of the MC strain. Binding of 125 I-PFEMP1 to ICAM-1 was measured with SDS extract of the ItG-ICAM strain. Blockade of PE adherence was tested with strain A4ultra.

Abbreviation: ND, not determined.

*No inhibition at the highest concentration tested.

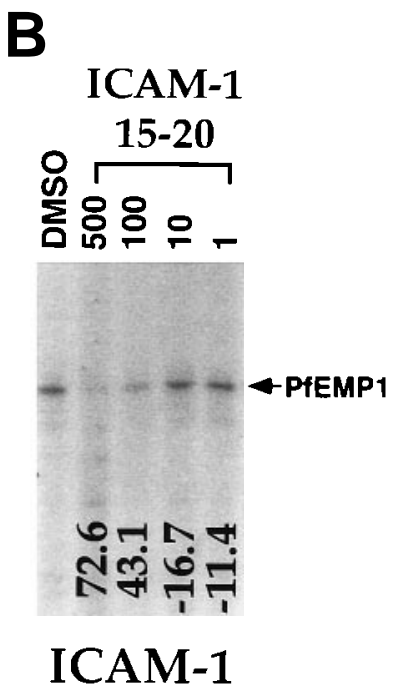

Fig 2. Concentration-dependent inhibition of binding of 125 PfEMP1 to CD36 and ICAM-1. (A) Inhibition of binding to CD36 using $\mathrm{MC} \mathrm{R}^{+}$SDS extract was performed as in Fig 1. Peptide concentration is given in $\mu \mathrm{mol} / \mathrm{L}$. The concentration of peptide CD36 397-409 was $500 \mu \mathrm{mol} / \mathrm{L}$. (B) Inhibition of binding to ICAM-1 using ItG-ICAM SDS extract was performed as in Fig 1 , except that the peptides were preincubated with the extract for 1 hour at room temperature. Peptide concentration is given in $\mu \mathrm{mol} / \mathrm{L}$ and all samples (except No DMSO) had a $5 \%$ final concentration of DMSO. The percent inhibition of binding from the DMSO control is indicated at the bottom of the figure.

effectively block the PfEMP1-CD36 interaction. However, differences in the $\mathrm{IC}_{50}$ (Table 2), measured at the low $\mu \mathrm{mol} / \mathrm{L}$ range are not affected by peptide solubility and represent true differences in the inhibitory activity of the different peptides.

CD36 and ICAM-1-derived peptides block PE adhesion. Peptide CD36 156-184 at a concentration of $100 \mu \mathrm{mol} / \mathrm{L}$ blocked PE adhesion to CD36 of strain A4ultra by more than $70 \%$ (Fig 4A), with an $\mathrm{IC}_{50}$ of about $25 \mu \mathrm{mol} / \mathrm{L}$ (Fig $4 \mathrm{C}$ and Table 2). Another peptide, CD36 145-171, with higher solubility than CD36 146-164 (but lower than CD36 156-184) blocked $\mathrm{PE}$ adhesion to CD36 with an $\mathrm{IC}_{50}$ of about $86 \mu \mathrm{mol} / \mathrm{L}$ (Fig 4C and Table 2). Other peptides tested, CD36 413-426, CD36 139-155, CD36 146-164, and ICAM-1 15-20 had no inhibitory effect on PE binding (Fig 4A). However, peptides CD36 139-155 and CD36 146-164 were only partially soluble at the 50 to $100 \mu \mathrm{mol} / \mathrm{L}$ concentration and failed to reach the high concentration necessary to block PE adhesion. This is particularly true for peptide CD36 139-155 that had much higher $\mathrm{IC}_{50}$ than the other peptides (Fig 3B and Table 2). The higher binding found with some of the peptides is attributed to the combined effect of both peptide and DMSO resulting in elevated adherence of PE or higher binding of PfEMP1 (see Figs 1 through 4 and D. Baruch, unpublished observation). In each case, the percent inhibition of adherence was calculated from the DMSO control (no peptide).

Peptide CD36 156-184 had no inhibitory effect on PE adherence to ICAM-1 (Fig 4B). The ICAM-1 15-20 peptide completely blocked adhesion to ICAM-1 at $500 \mu \mathrm{mol} / \mathrm{L}$ and more than $60 \%$ at $100 \mu \mathrm{mol} / \mathrm{L}$ (Fig 4B and Table 2) with an $\mathrm{IC}_{50}$ of about $97 \mu \mathrm{mol} / \mathrm{L}$, but had no effect on PE adhesion to CD36 (Fig 4A). These results demonstrate that the activity of the CD36 peptides and in particular CD36 156-184 is specific for PE adherence to CD36 and that the ICAM-1 15-20 peptide was specific for PE adherence to ICAM-1 (Fig 4).

\section{DISCUSSION}

Binding to CD36 plays a significant role in adherence of $P$. falciparum-infected erythrocytes. ${ }^{2,13-15}$ Antibodies that are able to block this interaction, such as 8A6, 10/5, and OKM5, recognize a single immunodominant domain (155-183) in 
A

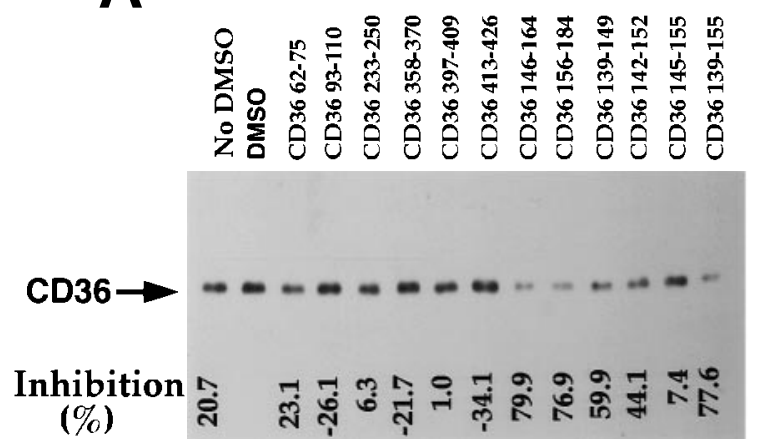

B

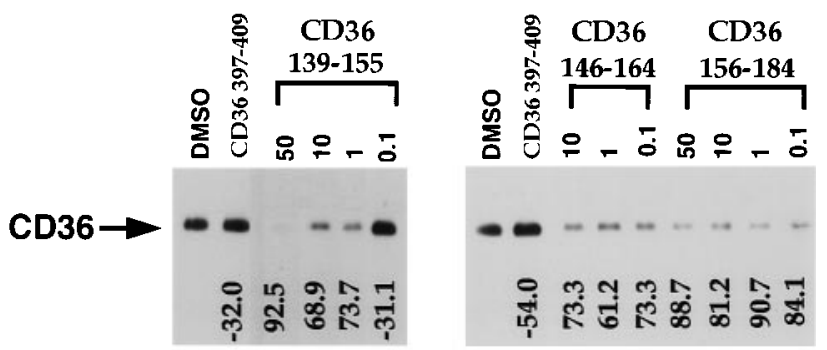

Fig 3. CD36 peptides inhibit the binding of rC1-2 [1-179] to CD36. Peptides were prepared in $0.45 \mathrm{~mL}$ of binding media pH 6.7 containing $1 \%$ BSA and 5\% DMSO and microfuged for 5 minutes before addition to the coated beads to remove insoluble peptide material. Peptides were incubated, 1 hour at room temperature with beads coated with rC1-2 [1-179] before addition of SCD36. After 3 hours incubation, the beads were washed and solubilized for SDS-PAGE. ${ }^{17}$ The binding of CD36 was assayed by Westem blot using biotinylated MoAb 179 recognizing a tag incorporated to the sequence of SCD36. ${ }^{17}$ All samples (except No DMSO) had a 5\% final concentration of DMSO. Percent inhibition of binding (from the DMSO control) is indicated at the bottom of the figure. Negative numbers means higher binding than the DMSO control. (A) Various CD36-derived peptides tested at $50 \mu \mathrm{mol} / \mathrm{L}$. (B) Concentration-dependent inhibition of binding of CD36 to rC1-2 [1-179]. Peptides concentration is in $\mu \mathrm{mol} / \mathrm{L}$. Peptide CD36 139-155 was largely insoluble at $100 \mu \mathrm{mol} / \mathrm{L}$ and peptide CD36 146-164 was only partially soluble at $50 \mu \mathrm{mol} / \mathrm{L}$. In both cases, most of the peptide was removed by the centrifugation step resulting in low to no inhibition (data not shown).

human CD36. ${ }^{39,40}$ However, the inhibitory MoAbs do not bind to mouse CD36 while PE do. ${ }^{40}$ The MoAbs also block the binding of ox-LDL residing well outside the immunodominant domain, ${ }^{37}$ indicating a possible conformational change in CD36 mediated by Ab binding. This suggests that the regions of CD36 recognized by $\mathrm{PE}$ and the inhibitory MoAbs may not be the same. Therefore, we tested peptides from the sequence of CD36 to identify the PE binding domain of CD36.

Three independent assays were applied to assess the ability of different peptides to block the PE or PfEMP1 interaction with CD36. We identified several peptides CD36 139-155, CD36
146-171, CD36 145-171, and CD36 156-184 to have blocking effect on binding to CD36 in 2 different assays. These peptides had no effect on binding to the host receptor ICAM-1, indicating that the inhibition is specific for CD36. These peptides derive from the extended immunodominant region of CD36 (139-183), as residues 139-155 are believed to contribute to the binding of the OKM5 and similar antibodies to CD36. ${ }^{27,39}$

Several other peptides CD36 62-75, CD36 233-250, CD36 139-149, and CD36 142-152 also gave partial blocking activity (Figs 1 and 3). However, these peptides were positive for inhibition only in 1 of the 3 assays used and were active at much
Fig 4. Blockade of PE adherence to immobilized CD36 and ICAM-1. PE from clone A4ultra were incubated for 1 hour in binding media containing the appropriate peptide and final concentration of $1 \%$ DMSO, then added to the spotted receptor for 1 hour and processed as described in Materials and Methods. Results are given as percent binding from the control (no peptide). (A) Blockade of adhesion to CD36 tested at $100 \mu \mathrm{mol} / \mathrm{L}$. MoAb 8 A6 was tested at $10 \mu \mathrm{g} /$ $\mathrm{mL}$. (B) Blockade of adherence to ICAM-1. Peptide CD36 156-184 was tested at $100 \mu \mathrm{mol} / \mathrm{L}$, peptide ICAM-1 15-20 was tested at 100 and $500 \mu \mathrm{mol} / \mathrm{L}$. (C) Concentration-dependent blockade of adherence to CD36. Peptide inhibition was tested at 1 to 100 $\mu \mathrm{mol} / \mathrm{L}$ range as described in (A).
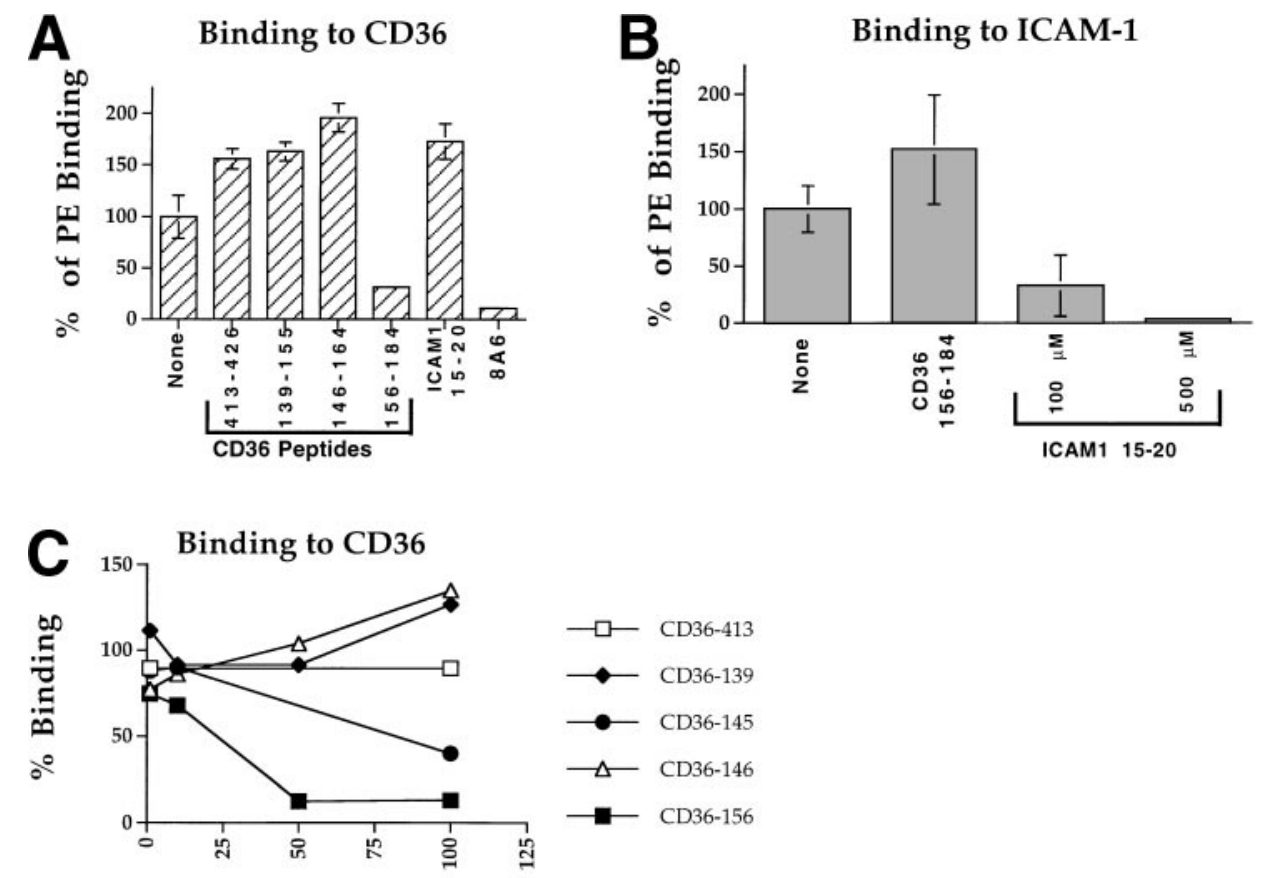

Peptide ( $\mu \mathrm{M})$ 
higher concentrations $\left(\mathrm{IC}_{50}>200 \mu \mathrm{mol} / \mathrm{L}\right)$ than the CD36 $139-184$ peptides $\left(\mathrm{IC}_{50}<5 \mu \mathrm{mol} / \mathrm{L}\right)$. In addition, none of these peptides blocked PE adhesion. Peptides CD36 97-110 and CD36 8-21 reported by Asch et $\mathrm{al}^{46}$ to block PE adhesion did not show any inhibition in our assays (CD36 97-110) or are lacking (CD36 8-21) from the soluble CD36 used here. Nevertheless, the possibility that the above residues contribute to the $\mathrm{PE}$ interaction with CD36 cannot be excluded.

Attempts to define the minimal binding domain were partially successful. Both peptides CD36 145-171 and CD36 146-164 were active, although only CD36 145-171 was able to block PE adhesion. Our attempts were complicated by the lack of solubility of the different peptides. Apart from CD36 156-184 and ICAM-1 15-20, which were readily soluble in aqueous solution, other peptides were much less soluble and could not be properly tested at high concentrations required for efficient inhibition. This is especially true in the PE blockade of adhesion assay where the DMSO content is restricted to maximum of $1 \%$ (compare with $5 \%$ in other assays). However, it is clear that although peptide CD36 139-155 was active, it displayed a much lower inhibition than the other 3 peptides (Table 2). Thus, we submit that the CD36 binding domain for PfEMP1 and infected erythrocyte is located at residues 139-184 of CD36 and in particular residues 145-171 or residues 146-164.

The PfEMP1 region corresponding to the $\mathrm{rC} 1-2$ [1-179] fragment of the CIDR-1 domain display significant variability among var genes including those originated from CD36 adherent parasites. ${ }^{17}$ Variation in the sequence of the CD36 binding domain, CIDR-1, and in binding domains for other host receptors, may result in qualitative and quantitative differences in adhesion of individual PE expressing PfEMP1 variants. These variations are expected to play a significant role governing the specific organ (eg, lung, heart, brain, placenta etc) and site of sequestration of individual PE. For example, PE sequestered in placenta binds to chondroitin sulfate A, but not to CD36. ${ }^{47}$ Although alternative recognition of residues of CD36 is possible, it appears that infected erythrocytes recognize the same CD36 domain, regardless of their variant sequences. The recombinant protein $\mathrm{rC} 1-2$ [1-179] blocked adhesion of all antigenically variant CD36-adherent $\mathrm{PE}$ tested. ${ }^{17}$ Also, the adhesion of various $P$. falciparum strains is blocked by Abs to the immunodominant domain of CD36. ${ }^{8,17,40}$ The peptides tested here provide additional support for a single adhesion region. These peptides inhibit the PE/PfEMP1 interaction with CD36 of 3 different strains, known to express different CIDR-1 sequences. ${ }^{16,17}$

Peptides from the CD36 139-184 region may have an anti-adhesion therapeutic potential. However, the high concentration needed for effective blockade of adherence and the relative low solubility of these peptides must be improved significantly for any possible anti-adherence therapeutics. In addition, several functions of CD36 may reside in this region or are influenced by $\mathrm{Ab}$ binding to this region, including binding of Ox-LDL, binding of fatty acids, phagocytosis of apoptotic neutrophils, and signal transduction properties. ${ }^{20,25,33,34,37}$ Adhesion of PE to this region may cause local inhibition or activation of some of the CD36-dependent processes on endothelial cells. Individuals who lack CD36 expression on monocytes are at risk of developing anti-CD36 antibodies $\left(\right.$ anti-NaK $\left.{ }^{\mathrm{a}}\right)$ directed against the $155-183$ region. ${ }^{36}$ The finding that infected erythrocytes bind to the CD36 multifunctional immunodominant domain raises the question of the effect of $\mathrm{PE}$ sequestration on CD36-dependent functions. Malaria-infected erythrocytes were found to activate monocytes and platelets, presumably by binding to CD36. ${ }^{25}$ Injection of peptides from the CD36 139-184 region may also have some adverse effect. However, it is conceivable that only a brief treatment will be required to affect $\mathrm{PE}$ adhesion resulting in release of sequestrating parasites to the circulation, without any prolonged adverse effect on the host.

In summary, we identified the extended immunodominant multifunctional domain of CD36 (residues 139-184) as the PE binding domain and in particular residues 145-171 and 146164. Peptides from this domain blocked PE adherence in vitro and may be of therapeutic value. These findings expand our knowledge about the molecular interactions between infected erythrocytes and CD36.

\section{ACKNOWLEDGMENT}

The authors thank Dr John Barnwell for providing MoAb 8A6 and Andrew Hutchinson for the ZZ-ICAM-1 recombinant protein.

\section{REFERENCES}

1. MacPherson GG, Warrell MG, White NJ, Looareesuwan S, Warrell DA: Human cerebral malaria: A quantitative ultrastructural analysis of parasitized erythrocyte sequestration. Am J Pathol 119:385, 1985

2. Howard RJ, Gilladoga AD: Molecular studies related to the pathogenesis of cerebral malaria. Blood 74:2603, 1989

3. Langreth SG, Peterson E: Pathogenicity, stability and immunogenicity of a knobless clone of Plasmodium falciparum in Colombian owl monkeys. Infect Immun 47:760, 1985

4. Miller LH, Good MF, Milon G: Malaria pathogenesis. Science 264:1878, 1994

5. Turner GDH, Morrison H, Jones M, Davis TME, Looareesuwan S, Buley ID, Gatter KC, Newbold CI, Pukritayakamee S, Nagachinta B, White NJ, Berendt AR: An immunohistochemical study of the pathology of fatal malaria. Am J Pathol 145:1057, 1994

6. Turner G: Cerebral malaria. Brain Pathol 7:569, 1997

7. Roberts DD, Sherwood JA, Spitanlink SL, Panton LJ, Howard RJ, Dixit VM, Frazier WA, Miller LH, Ginsburg V: Thrombospondin binds falciparum malaria parasitized erythrocytes and may mediate cytoadherence. Nature 318:64, 1985

8. Barnwell JW, Ockenhouse CF, Knowles Dd: Monoclonal antibody OKM5 inhibits the in vitro binding of Plasmodium falciparuminfected erythrocytes to monocytes, endothelial, and C32 melanoma cells. J Immunol 135:3494, 1985

9. Berendt AR, Simmons DL, Tansey J, Newbold CI, Marsh K: Intercellular adhesion molecule-1 is an endothelial cell adhesion receptor for Plasmodium falciparum. Nature 341:57, 1989

10. Rogerson SJ, Chaiyaroj SC, Ng K, Reeder JC, Brown GV: Chondroitin sulfate $\mathrm{a}$ is a cell surface receptor for plasmodium falciparum-infected erythrocytes. J Exp Med 182:15, 1995

11. Treutiger CJ, Heddini A, Fernandez V, Muller WA, Wahlgren M: PECAM-1/CD31, an endothelial receptor for binding Plasmodium falciparum-infected erythrocytes. Nat Med 3:1315, 1997

12. Ockenhouse CF, Tegoshi T, Maeno Y, Benjamin C, Ho M, Kan KE, Thway Y, Win K, Aikawa M, Lobb RR: Human vascular endothelial cell adhesion receptors for Plasmodium falciparum-infected erythrocytes: Roles for endothelial leukocyte adhesion molecule 1 and vascular cell adhesion molecule 1. J Exp Med 176:1183, 1992 
13. Newbold C, Warn P, Black G, Berendt A, Craig A, Snow B, Msobo M, Peshu N, Marsh K: Receptor-specific adhesion and clinicaldisease in plasmodium-falciparum. Am J Trop Med Hyg 57:389, 1997

14. Ockenhouse CF, Ho M, Tandon NN, Van Seventer GA, Shaw S, White NJ, Jamieson GA, Chulay JD, Webster HK: Molecular basis of sequestration in severe and uncomplicated Plasmodium falciparum malaria: Differential adhesion of infected erythrocytes to CD36 and ICAM-1. J Infect Dis 164:163, 1991

15. Cooke BM, Berendt AR, Craig AG, Mac Gregor J, Newbold CI, Nash GB: Rolling and stationary cytoadhesion of red blood cells parasitized by Plasmodium falciparum: Separate roles for ICAM-1, CD36 and thrombospondin. Br J Haematol 87:162, 1994

16. Smith JD, Kyes S, Craig AG, Fagan T, Hudson-Taylor D, Miller LH, Baruch DI, Newbold CI: Analysis of adhesive domains from the A4VAR Plasmodium falciparum erythrocyte membrane protein-1 identifies a CD36 binding domain. Mol Biochemical Parasitol 97:133, 1998

17. Baruch DI, Ma XC, Singh HB, Bi XH, Pasloske BL, Howard RJ: Identification of a region of Pfemp1 that mediates adherence of plasmodium-falciparum-infected erythrocytes to Cd36-conserved function with variant sequence. Blood 90:3766, 1997

18. Knowles DMD, Tolidjian B, Marboe C, D'Agati V, Grimes M, Chess L: Monoclonal anti-human monocyte antibodies OKM1 and OKM5 possess distinctive tissue distributions including differential reactivity with vascular endothelium. J Immunol 132:2170, 1984

19. Kuzu I, Bicknell R, Harris AL, Jones M, Gatter KC, Mason DY: Heterogeneity of vascular endothelial cells with relevance to diagnosis of vascular tumours. J Clin Pathol 45:143, 1992

20. Daviet L, McGregor JL: Vascular Biology of Cd36 - roles of this new adhesion molecule family in different disease states. Thromb Haemost 78:65, 1997

21. Acton SL, Scherer PE, Lodish HF, Krieger M: Expression cloning of SR-BI, a CD36-related class B scavenger receptor. J Biol Chem 269:21003, 1994

22. Calvo D, Dopazo J, Vega MA: The CD36, CLA-1 (CD36L1), and LIMPII (CD36L2) gene family: Cellular distribution, chromosomal location, and genetic evolution. Genomics 25:100, 1995

23. Ren Y, Silverstein RL, Allen J, Savill J: CD36 gene transfer confers capacity for phagocytosis of cells undergoing apoptosis. J Exp Med 181:1857, 1995

24. Rigotti A, Acton SL, Krieger M: The class B scavenger receptors SR-BI and CD36 are receptors for anionic phospholipids. J Biol Chem 270:16221, 1995

25. Ockenhouse CF, Magowan C, Chulay JD: Activation of monocytes and platelets by monoclonal antibodies or malaria-infected erythrocytes binding to the CD36 surface receptor in vitro. J Clin Invest $84: 468,1989$

26. Lipsky RH, Eckert DM, Tang Y, Ockenhouse CF: The carboxylterminal cytoplasmic domain of CD36 is required for oxidized lowdensity lipoprotein modulation of NF-kappaB activity by tumor necrosis factor-alpha. Recept Signal Transduct 7:1, 1997

27. Leung LL, Li WX, McGregor JL, Albrecht G, Howard RJ: CD36 peptides enhance or inhibit CD36-thrombospondin binding. A two-step process of ligand-receptor interaction. J Biol Chem 267:18244, 1992

28. Greenwalt DE, Lipsky RH, Ockenhouse CF, Ikeda H, Tandon NN, Jamieson GA: Membrane glycoprotein CD36: A review of its roles in adherence, signal transduction, and transfusion medicine. Blood 80:1105, 1992

29. Endemann G, Stanton LW, Madden KS, Bryant CM, White RT, Protter AA: CD36 is a receptor for oxidized low density lipoprotein. J Biol Chem 268:11811, 1993

30. Abumrad NA, el-Maghrabi MR, Amri EZ, Lopez E, Grimaldi PA: Cloning of a rat adipocyte membrane protein implicated in binding or transport of long-chain fatty acids that is induced during preadipocyte differentiation. Homology with human CD36. J Biol Chem 268:17665, 1993
31. Mercier N, Catimel B, Reck MP, Pellecchia D, McGregor JL: Identification of a functional site on CD36 involved in the interaction between platelets and collagen. Platelets 6:139, 1995

32. Pearce SFA, Wu J, Silverstein RL: Recombinant GST/CD36 fusion proteins define a thrombospondin binding domain. Evidence for a single calcium-dependent binding site on CD36. J Biol Chem 270:2981, 1995

33. Navazo MD, Daviet L, Savill J, Ren Y, Leung LL, McGregor JL: Identification of a domain (155-183) on CD36 implicated in the phagocytosis of apoptotic neutrophils. J Biol Chem 271:15381, 1996

34. Navazo MDP, Daviet L, Ninio E, Mcgregor JL: Identification on human CD36 of a domain (155-183) implicated in binding oxidized low-density lipoproteins (Ox-LDL). Arterioscler Thromb Vasc Biol 16:1033, 1996

35. Baruch DI, Gormley JA, Ma C, Howard RJ, Pasloske BL: Plasmodium falciparum erythrocyte membrane protein 1 is a parasitized erythrocyte receptor for adherence to CD36, thrombospondin, and intercellular adhesion molecule 1. Proc Natl Acad Sci USA 93:3497, 1996

36. Daviet L, Morel-Kopp MC, Kaplan C, McGregor JL: A structural/ functional domain on human CD36 is involved in the binding of anti-Nak(a) antibodies. Thromb Haemost 73:543, 1995

37. Pearce SF, Roy P, Nicholson AC, Hajjar DP, Febbraio M, Silverstein RL: Recombinant gluthathione S-transferase/CD36 fusion proteins define an oxidized low density lipoprotein-binding domain. J Biol Chem 273:34875, 1998

38. Li WX, Howard RJ, Leung LL: Identification of SVTCG in thrombospondin as the conformation-dependent, high affinity binding site for its receptor, CD36. J Biol Chem 268:16179, 1993

39. Daviet L, Buckland R, Puente Navazo MD, McGregor JL: Identification of an immunodominant functional domain on human CD36 antigen using human-mouse chimaeric proteins and homologuereplacement mutagenesis. Biochem J 305:221, 1995

40. Daviet L, Craig AG, McGregor L, Pinches R, Wild TF, Berendt AR, Newbold CI, McGregor JL: Characterization of 2 vaccinia Cd36 recombinant-virus-generated monoclonal-antibodies $(10 / 5,13 / 10)$ effects on malarial cytoadherence and platelet functions. Eur J Biochem 243:344, 1997

41. Baruch DI, Pasloske BL, Singh HB, Bi X, Ma XC, Feldman M, Taraschi TF, Howard RJ: Cloning the $P$. falciparum gene encoding PfEMP1, a malarial variant antigen and adherence receptor on the surface of parasitized human erythrocytes. Cell 82:77, 1995

42. Hasler T, Albrecht GR, Van Schravendijk MR, Aguiar JC, Morehead KE, Pasloske BL, Ma C, Barnwell JW, Greenwood B, Howard RJ: An improved microassay for Plasmodium falciparum cytoadherence using stable transformants of Chinese hamster ovary cells expressing CD36 or intercellular adhesion molecule-1. Am J Trop Med Hyg 48:332, 1993

43. Su X-Z, Heatwole V, Wertheimer SP, Guinet F, Herrfeldt JA, Peterson DS, Ravetch JA, Wellems TE: The large and diverse gene family var encodes proteins involved in the cytoadherence and antigenic variation of Plasmodium falciparum-infected erythrocytes. Cell $82: 89,1995$

44. Ockenhouse CF, Betageri R, Springer TA, Staunton TE: Plasmodium falciparum-infected erythrocytes bind ICAM-1 at a site distinct from LFA-1, Mac-1, and human rhinovirus. Cell 68:63, 1992

45. Gardner JP, Pinches RA, Roberts DJ, Newbold CI: Variant antigens and endothelial receptor adhesion in plasmodium falciparum. Proc Natl Acad Sci USA 93:3503, 1996

46. Asch AS, Liu I, Briccetti FM, Barnwell JW, Kwakye-Berko F, Dokun A, Goldberger J, Pernambuco M: Analysis of CD36 binding domains: Ligand specificity controlled by dephosphorylation of an ectodomain. Science 262:1436, 1993

47. Fried M, Duffy PE: Adherence of Plasmodium falciparum chondroitin sulfate A in the human placenta. Science 272:1502, 1996 